\title{
Environmental scanning for business planning a total (holistic) approach is necessary
}

\author{
C.H. Boshoff \\ Director, Institute for Future Studies, Potchefstroom University for CHE
}

\begin{abstract}
Traditionally environmental scanning for purposes of business planning was done in a compartementalized way in the sense that each influence was studied under the assumption that all other influences would remain constant. In a dynamic society where environmental change takes place at an accelerated pace, a total (integrated or holistic) approach to environmental scanning as the basis for business planning becomes necessary. This need will be demonstrated by way of examples in this paper in a twofold way. First, that the accelerated pace of change in the environmental influences is such that their implications for business planning can change even in the short run. Secondly, that the resultant cross impact of these changes invalidates the continuation of the trend-line approach as far as the result of the environmental influences on business planning is concerned.
\end{abstract}

S. Afr. J. Bus. Mgmt. 1981, 12: 38-43

Tradisioneel was omgewingsverkenning as basis vir besigheidsbeplanning gekompartementaliseerd gedoen deurdat elke invloed bestudeer is onder die aanname dat alle ander invloede as konstantes beskou kan word. In 'n dinamiese gemeenskap waarin die pas van omgewingsveranderinge almeer versnel, is ' $n$ totale (geïntegreerde of holistiese) benadering in diè verband essensieel as basis vir besigheidsbeplanning. Hierdie behoefte word op tweërlei wyse met behulp van voorbeelde in hierdie artikel geïllustreer. Eerstens, dat die versnelde tempo van verandering in omgewingsinvloede sodanig is dat dit selfs oor die kort termyn veranderde implikasies vir besigheidsbeplanning kan hê. Tweedens, dat die gevolglike kruisimpak tussen omgewingsinvloede in die proses van verandering se invloed op beplanning selde as ' $n$ voortsetting van die historiese neigingslyn geneem kan word. S.-Afr. Tydskr. Bedryfsl. 1981, 12: 38- 43
Scanning of the business environment in order to take these influences into account in the planning process has come a long way. Traditionally this scanning was mostly done in a compartementalized way. Each influence was treated in isolation in the planning process under the assumption that all other influences would remain constant.

In the dynamic society of today where environmental change takes place at an accelerated pace, this is no longer a valid approach. A total (integrated or holistic) approach to environmental scanning as the basis for business planning becomes necessary. Most of the data used in this paper was obtained through a study visit to the planning departments of some of the big US corporations, as well as institutions conducting public opinion polls in the USA. Although the examples used are more applicable to the American situation, they serve to underline the basic theme of this paper.

\section{The elements of business planning}

Business planning can usually be seen as illustrated in Fig. 1.

The goals of the business is made operational through the various decision-making functions in the corporate sub-system. The functioning (and therefore planning) of these functions is in turn governed by various internal and external influences.

The internal influences are those governing the efficient functioning of these functions. Because they are usually internal to the working of the corporation itself, they are normally fully controllable. It is therefore relatively easy to take them into account in the planning process. The resultant planning is usually short term in nature.

The most important characteristic of the external (environmental) influences is that the corporation cannot normally influence its course and scope. They usually have to be taken into account in the planning process on an overcoming of the problem approach. Furthermore, because changes in these influences are usually more structural in nature, the resultant planning based on these influences is more long term in nature. As far as longrange (strategic) planning is concerned, these environmental influences are usually of much more importance.

Historically, only the economic influences/changes in 


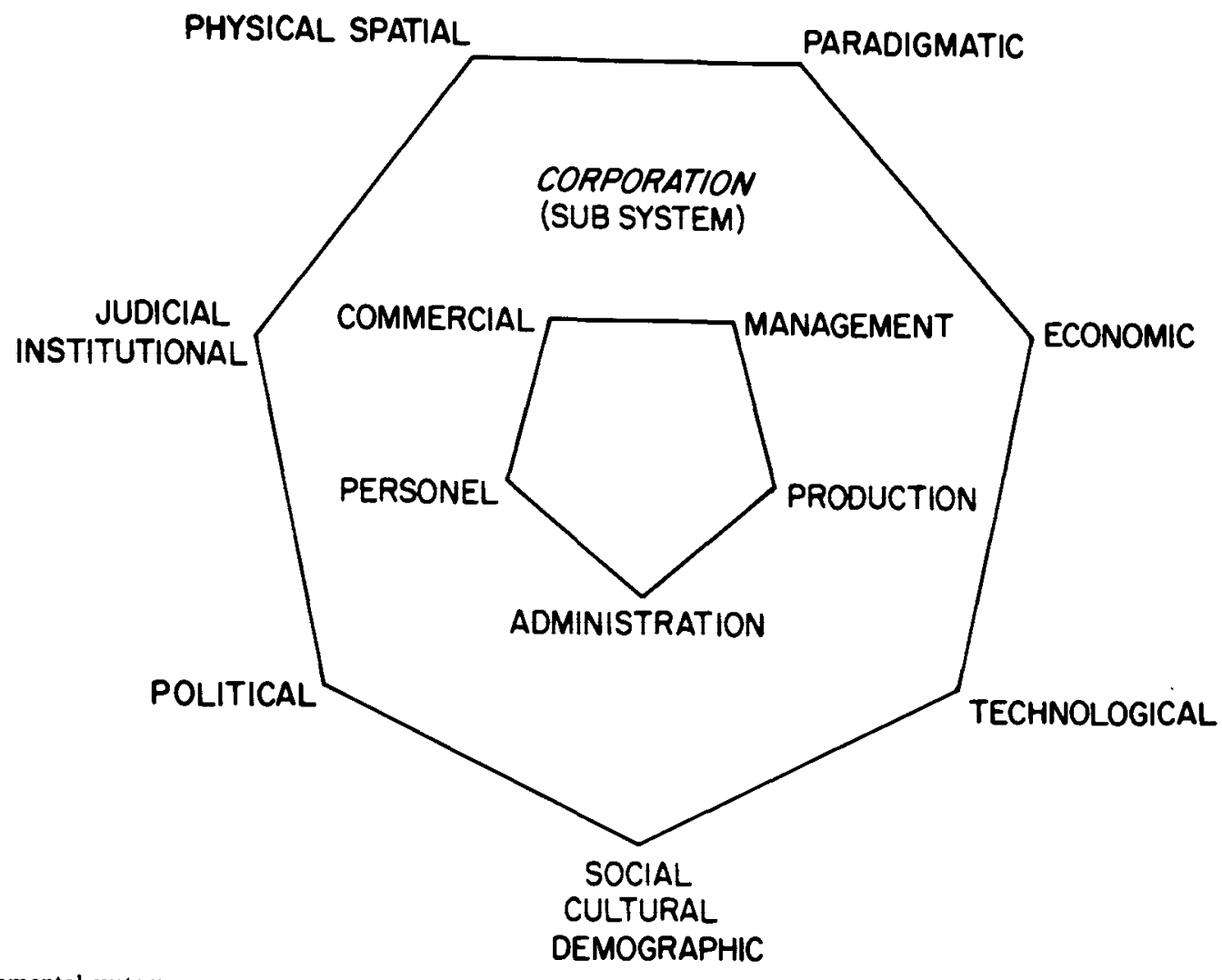

Fig. 1 Environmental system.

the environmental system were taken into account in the process of environmental scanning and monitoring.

The rationale for this was the assumption that changes in the other environmental influences were usually assumed to be gradual and long term in nature. If they did not change, they could be treated as constants in the planning process. Furthermore, economic growth was assumed to be self perpetuating in nature. This resulted in the fact that economic influences were forecasted on a continuation of the trendline approach.

This concentration on the economic environment and the resultant trendline forecasting to the exclusion of other environmental influences is becoming less valid today. The first reason lies in the planning crisis that followed the 1973 oil crisis. For business it was an unexpected shock; for business planning - a disaster. The sudden and abrupt halt of the continuous upward movement of the economy literally pulled the rug from under a vast number of company plans. The assumptions on which they had been based were no longer valid and many plans had to be abandoned. Much of traditional business planning had been based on the tacit assumption that future developments would more or less be a continuation of the trendline and could therefore be predicted with reasonable accuracy. This assumption could no longer be maintained. Non-economic influences could be so strong that it could halt the thrust of the economic trend.

The second reason lies in the realization that social, cultural, political and paradigmatic changes have accelerated to the point where they cannot be treated as constants even for as short as a five-year planning horizon. This means that economic forecasting in isolation from other environmental change is only valid in the short run. If this is the case, continuation of the trendline approach as far as long-range planning is concerned, becomes more and more invalid. This is the case because the interface between the various influences (for example between economic and social) often results in a quite different economic future than would have been the case had all other factors been constants. A total systematic approach to environmental scanning and monitoring is therefore the only valid one when taking these influences into account for the planning process. The need for this will be demonstrated by way of examples later in the article. These examples will try to illustrate two things. First, that the accelerated pace of change in the environmental influences is such that their implications for the business functions and planning can change even in the short run. The assumption as to their constancy is no longer valid. - Secondly, that the resultant cross impact of these changes invalidates the continuation of the trendline approach as far as the result of the environmental influences on the business functions is concerned.

\section{The necessity for a total (holistic) approach to en- vironmental scanning}

The economic environment

As far as the economic influence is concerned, it is usually treated under the assumption that all other environmental influences are constants. As far as the elements of the economic influence are concerned, economic rationality is assumed. In taking consumption as an example it can be stated that, because economic principles will guide man's decision-making, it can only be treated as a function of disposable income. We need, therefore, only to know what the future trend in disposable income will be as the basis for planning the commercial function of business. 
For an increasing section of consumers this marginal utility approach is no longer valid. At the lower stages of economic development man is forced to dispose of his income in the most economic way. As income increases over time and people rise above the so-called breadline, consumption becomes more and more a function of income plus other non-economic factors. In this respect Katona' distinguishes between 'ability to buy' (which is a function of income) and 'willingness to buy' (which is a function of non-economic factors). In such a society economic and social trends, as well as the interface between them, have to be taken into account as the basis for planning. Continuation of the trendline as far as economic influences are concerned, therefore becomes a less valid approach for incorporating these influences into the planning process.

During the sixties, and to a lesser extent the seventies, a continuous upward growth trend was assumed to be the normal situation. This is no longer the case today and the first reason for this stems from the emergence of the Opec oil cartel. This has already changed the notion of perennial growth, and related to this is the increasing effort of third world nations to boost their own economies through further refinement of their raw materials.

Although it might prove impossible to achieve, the possibility exists that the present oil cartel could be extended to include certain strategic raw materials. Even if it did not succeed, the Opec cartel has brought a new determinant to economic growth. Traditionally, labour, capital and technology were the main determinants of economic growth. Today, and even more so in future, oil and strategic minerals, politics and geography, as well as the interface between these environmental factors and the economy, have a profound influence on economic growth. Monitoring of the influences determining economic growth in the process of environmental scanning must also include the physical/spatial and political environment and its interface with the economic environment. For example, a repetition of the Iranian situation in Saudi Arabia could plunge the world economy in another protracted recession and it is important for business planning to take such possibilities into account.

\section{The social environment}

As far as the social environment is concerned, it was usually assumed that change is slow and that it would pass unnoticed in one person's lifetime. It could therefore be treated as a constant in the planning process but this is no longer the case. Social change today is a real phenomenon, having a profound influence on the various corporate functions and the planning process. In the nineteenth century lifestyle and social class were synonymous and certain lifestyles belonged to a certain class of which dress, dwelling place and the means of transportation were its visual signs. Tradition determined lifestyle, careers, buying patterns etc. (Toffler, ${ }^{2 p}{ }^{276}$ ). Because tradition was very strong, these patterns did not change and its implication for marketing and the planning process therefore remained the same.

At present lifestyle and social standing are no longer synonymous, and not social standing, but rather affiliation to a certain subculture forms the basis of lifestyle. The dropout from the working class and the one from the upper class share the same lifestyle, but not the same social class. The same applies to modes of transportation. Motorcycling as a means of transportation is common amongst people of all walks of life. The result is that these subcults, with models and heroes as leaders, today determine the lifestyles of people drawn from all social classes. This fact erodes the traditional rigid basis of lifestyle based on social class, and brings about often and rapid change. Social mobility therefore not only takes place between economic classes; but more often from one subculture to another. People easily rid themselves of the symbols of their links to an outdated subculture and replace these with new items emblematic of their new identification.

The implication this has on the marketing and planning process is quite clear. No business can assume that new customers in a certain suburb will have the same 'tastes' as the old ones. There is no certainty that the children will follow the parents as far as buying patterns are concerned and that fewer products will have a long shelf life. Production and marketing functions will therefore have to be more flexible in nature.

\section{The paradigmatic environment}

Related to this, shifts in the dominant paradigm of man at present occur in a relatively short time period, resulting in profound changes in business planning. During the sixties the USA society was characterized by a material paradigm. $\mathrm{Kuhn}^{3}$ uses the term 'dominant paradigm' to signify the basic way of perceiving, thinking and doing that is associated with a particular vision of reality. The characteristics of this material paradigm were (Har$\operatorname{man}^{4, p 5}$ )

- the development and application of the scientific method, and the wedding of science to technological advance;

- industrialization through the organization and division of labour;

- acquisative materialism as a dominant value;

- the work ethic;

- an economic image of man;

- belief in unlimited material progress and in technological and economic growth.

This resulted in the belief that the goal for all Americans was a middle-class lifestyle - and the means to that end were technological progress, the Puritan Ethic of hard work and self-denial, as well as a positive program of stimulating economic growth.

During the fifties and sixties a buoyant economy and government programmes created conditions conducive to affluence. The dream of material upward mobility became less of a dream and more of a reality. But in a smaller group this new affluence - with its builtin optimism about even greater affluence - created new attitudes. These people began to question self-denial. If the country was rich enough for all of its citizens to share in the good life, then to struggle for your share seemed unnecessary. This group - mostly well educated and affluent - raised its children to believe that life need not be dominated by economic struggle. It was these children who, in the sixties, provided the first open challenge to 
the established materialistic American way of life. This movement rapidly gained momentum during the seventies, with the following characteristics:

- the questioning of self denial and hard work;

- more pre-occupation with the question of how to live life instead of the question of how to make a living;

- the belief that, what counts most in life is individual growth and that man must have the opportunity to fulfil his own potential.

Man has a moral responsibility towards himself in this respect and where society was traditionally characterized by a vertical social and power structure, it is increasingly becoming horizontalized. It is fast changing from a we (centralized) to a me (decentralized) society. In other words, it is changing from we (self-sacrificing) to me (pursuit of the full rich life) values.

The extent of this social/paradigmatic revolution can be seen from the Yankelovich social monitor which is yearly conducted on a nationwide scale. They found that in 1979 the retreators and traditionalists, the people representing the traditional values of the system, formed $16 \%$ of the population. In 1970 they still represented $38 \%$. The aimless group, motivated by pleasure and sensation, today forms $17 \%$. The self-achievement group, which still believes in hard work, self-achievement and inner growth through one's career, today forms $33 \%$. The personal experienced group, which is growing and is motivated by the search for pleasure, new experiences and an unconventional lifestyle, forms $34 \%$ of the population.

The marketing and production implications of this paradigmatic change is interesting. At least they do not represent a continuation of the historical trendline of the materialistic society of the sixties. Among the personal experienced group (group A) the need to keep up with new styles as far as fashion is concerned, is overwhelming. This need drops dramatically among the selfachievement group (group B) and is virtually non-existent among the traditionalists (group $C$ ). An expensive car ranks high among group $A$, but not in the case of group B. On the other hand, it is an important symbol among group C. Apart from lower productivity as a reason, this changed social structure was one of the main reasons for the present problems in the automobile industry. Because group $\mathrm{C}$ was dominant in the sixties, material symbols such as big, expensive cars were very important. In the seventies money and material things as the only sign of success were very low on the preference scale of group A and B. Although the love affair of the American people with the big, expensive car is still dominant among group $\mathrm{C}$ people, they form a dwindling minority. This caught the automobile industry unprepared. Their planning for the seventies was based mainly on a continuation of the historical economic (rising disposable income) and social (materialistic values) trends. The oil crisis, which brought about change in the physical/spatial environment, was another discontinuation of historical trends that they did not foresee.

Another interesting example which highlights these differences concerns prices. Where the traditionalists are very price conscious, this is less so among the selfachievement group. The rating is even lower among the personal experience group. This trend fits in well with the findings of a Stanford Research International survey among USA business as to their opinion of the most pressing problems for business in the eighties. Apart from the more obvious ones such as energy and the economy, credibility of business ranked third. In a society where non-materialistic values are gaining in importance, price is not the only buyers motivation. The credibility image of the business forms an increasingly important part of its marketing strategy and planning.

This social/paradigmatic change also has a profound influence on the management function of business. Traditionally management was only responsible to the shareholders. In a materialistic society a fair return on capital was the main concern of management but the emergence of non-materialistic values have increased the scope of shareholder's interests in the business. Management are increasingly forced to take these interests into account and the old idea of 'what is good for General Motors shareholders is good for the country' is rapidly losing its credibility. This resulted in the idea of strategic performance management in which the notion of adaptation to the changes in the total environmental system plays a key role. More and more, management has to spend its time outside the business, analysing the environment and planning to adapt to it. This contrasts with the old notion that the place of management is inside the business and that it is only concerned with matters of a purely economic nature.

These social and paradigmatic changes will in turn influence the personnel function of business. The move from a structured to a more unstructured society will increasingly emphasize the me instead of the we matters in business. The questioning of blind obedience to hierarchical structures and decision-making procedures will gain in importance. Privacy of the worker, his rights as a human being, pensions etc. will gain in importance. The motivation that actions are taken to benefit the company (or to improve profits) will become less popular; work will increasingly have to be geared around the notion of self-achievement.

The interface between the paradigmatic and economic environment

Changed social and paradigmatic trends will also in turn influence the economic and technological aspect of the corporate environment. The growth in the non-material paradigm results more and more in the changing of the 'growth is good' syndrome to a 'reasonable or selective' growth syndrome. This will of course be strengthened by the oil crisis, the realization that the world does not have unlimited natural resources and the high inflation rate. The 'American dream' that the pot at the end of the rainbow is material wealth, is losing its credibility in an era in which people place growing importance on cultural and spiritual values as a means of obtaining a full rich live. A lifestyle in which equilibrium between spiritual and material values is fast developing. There is a growing realization among Americans that social and moral factors, instead of material barriers (such as energy, labour, capital) will determine the pace of economic growth in the eighties. This interface between the social, paradimatic and economic environment will in turn have 
profound influence on the business functions and planning.

The interface between the social paradigmatic and technological environment

A similar interface is building up between the social and technological environment. Traditionally technological growth was seen as exponential in nature. Once a new technology was discovered, its operationalization was only a matter of time. Furthermore, its growth path was assumed to be exponential in nature. The assumption was that if the new technology was capable of producing a new product, there would be a ready market for it. Further, if it can be sold, it is good for the individual and the economy.

This reasoning is increasingly coming under pressure today. This is because of the growth of the idea of social acceptable technology. That is, the results of the technology must fit in with the value systems of the people. Because the old materialistic value systems are increasingly supplemented by non-material values, new technology is no longer only judged by its economic results. Nuclear power is a good example. Although it has the potential of supplying cheap energy, the social opposition to nuclear plants prohibits this development. West Germany, for instance, is falling behind schedule in its nuclear power programme because of social opposition. A further example is the growing resistance to technology that displaces people. The fact that the end result is a cheaper product, is no longer acceptable.

\section{Methodological implications of a holistic environ- mental scanning approach}

Although it is not the theme of this paper, certain methodological principles flow logically from these examples:

- There is no such thing as a blueprint as far as methodology is concerned. Because we are working with the future, we are working with uncertainty. This uncertainty is aggrevated by the fact that the influence of man on environmental factors is not always rational.

- The methodology must suit the needs of the corporation. To be worthwhile and useful, an environmental scanning and planning system has to be an organic part of a company's lifestyle and philosophy. To achieve this, the planning process will have to be thoroughly understood and tailord to the specific needs of each individual company.

- Environmental scanning cannot be done on a compartementalized basis, especially in the field of medium and long-term planning.

- Forecasting of environmental influences has to be treated with caution. (Seidl, , p.7). 'We believe in planning: not in numerical forecasts but in hard thought which aims to identify a consistant pattern of economic and social forecasting.'

- There is an increase in the soft-system approach to environmental scanning. People are realizing more and more that the interface between the environmental influences are sometimes more important than the trendline in the individual influence itself. Fur- thermore, that this interface is influenced by human behaviour. Although man is supposed to act rationally, this does not always happen in practice. This implies that a logical relation between the social and economic environment cannot be assumed to be a causal one, resulting more in a reliance on a human scanning and information network than on a computer based one. My experience, after visiting some of these big corporations, is that those who do not have a blueprint as far as methodology is concerned, have more successful programmes of environmental scanning. Shell International is a good example in this respect. Their scenarios on possible environmental developments are 'short on figures and strong on qualitative arguments'. (Lorenz, ${ }^{6, p .19}$ ).

- The resultant planning must be flexible in nature. Because of the accelerated pace of change in environmental influences and because the interface between them is more often non-causal in nature, it is impossible to forecast the future, and very dangerous to do so. We can only talk of possibilities as far as the future is concerned; very seldom of facts. This can best be explained by the distinction between the Latin words facta and futura (de Jouverel, '). Facta (facts) has to do with that which is known because it has happened and could therefore be verified. Futura, on the other hand, is derived from the noun esse (to be) and has therefore to do with the future. Only if uncertainty about the future can be excluded, can future facts (thus projection) be relevant. Because this is impossible, futura can only be a future image or possibility.

- This implies that environmental scanning and 'forecasting' cannot be forecasting in the sense of a single future. The result must rather be a fan of possible futures built on the present facts and their possible directions. In fact, in a dynamic society one is not even sure that all these possibilities will materialize, or in which order. The most one can do is to determine which of these possibilities has the greatest potential to materialize. This then forms the planning cone into which the resultant business planning must fit, and means that the process of environmental scanning must be updated on a continuous basis and, that the resultant planning must be flexible and not rigit in nature.

- It is clear that a compartementalized approach to management training cannot be valid any more. The same applies to specialization. In a situation of rapid environmental change, management training (and experience) must increasingly focus on holistic problem solving; management of situations instead of compartementalized functions. Unless this is done, the manager would not be able to understand the complex environmental changes to which his business must adapt to survive.

\section{References}

1 KATONA, G. Survey of consumer finances. Survey research centre, University of Michigan. Ann Abor, Michigan, 1968.

2 TOFFLER, A. Future Shock. The Bodley Head, London, 1970.

3 KUHN, T.S. The structure of scientific revolutions. University of Chicago Press, Chicago, 1962. 
4 HARMAN, W.W. An incomplete guide to the future. The Portable Stanford Series. San Francisco Book Co., San Francisco, 1976.

5 SEIDL, R.G. How useful is corporate planning today? Paper presented to the 1979 corporate finance conference. October 10 ,
London, 1979.

6 LORENZ, C. Shell strikes a refined way of explaining the future. Financial Times, March 4, 1980.

7 DE JOUVENEL, B. The art of Conjecture. Basic Books Inc. New York, 1967. 